\title{
Ruthenium Olefin Metathesis Catalysts Containing Fluoride
}

\author{
Stefano Guidone, ${ }^{\dagger}$ Olivier Songis, ${ }^{\dagger}$ Laura Falivene, ${ }^{\ddagger}$ Fady Nahra, ${ }^{\dagger}$ Alexandra M. Z. Slawin, ${ }^{\dagger}$ \\ Heiko Jacobsen, ${ }^{\S}$ Luigi Cavallo, ${ }^{\ddagger}$ and Catherine S. J. Cazin*, ${ }^{\star}$ \\ ${ }^{\dagger}$ EaStCHEM School of Chemistry, University of St Andrews, St Andrews KY16 9ST, UK. \\ ${ }^{\ddagger}$ Physical Sciences and Engineering, Catalysis Center, King Abdullah University of Science and Technology \\ (KAUST), Thuwal 23955-6900, Saudi Arabia
}

${ }^{\S}$ KemKom, 1215 Ursulines Avenue, New Orleans, Louisiana 70116, United States

\begin{abstract}
The reaction of the ruthenium complex cis-Caz-1 with silver fluoride affords the first example of an active olefin metathesis pre-catalyst containing fluoride ligands. The cis geometry of the precursor complex is key to the successful fluoride exchange reaction. Computational studies highlight the stability of the new Ru-F species, due to pushpull interactions between fluoride and L-type ligands ( $\mathrm{L}$ : N-heterocyclic carbene, phosphite). Insights into the isomerization process from trans-Caz-1 to cis-Caz-1 are given. Fluoride exchange reactions were performed involving cis- and trans-Caz-1 complexes. Catalytic tests showcase the excellent activity of the Ru-F containing complexes.
\end{abstract}

KEYWORDS olefin metathesis, homogeneous catalysis, ruthenium, fluoride, halide exchange.

\section{Introduction}

The introduction of fluorine atoms in molecules can drastically change their physical and chemical properties. ${ }^{1}$ Organofluorine compounds are nowadays employed in the agrochemical and pharmaceutical industry, with an ever increasing demand for this class of compounds. ${ }^{2}$ Fluorine has been introduced into metal-complexes as fluoride ligand. ${ }^{3}$ Late-transition-metal fluoride complexes represent a challenge in synthetic organometallic chemistry due to the hard-soft mismatch. ${ }^{2,4}$ As a result, only a limited number of examples of transition metal fluoride complexes (namely $\mathrm{Pd}^{5 \mathrm{a}} \mathrm{Pt}^{5 \mathrm{~b}} \mathrm{Ir}^{5 \mathrm{c}} \mathrm{Os}^{5 \mathrm{d-f}}$ and $\mathrm{Ru}^{5 \mathrm{e-k}}$ ) has been disclosed to date. Most synthetic protocols leading to $\mathrm{M}-\mathrm{F}$ bond formation involve an oxidative addition of $\mathrm{XeF}_{2}$ in anhydrous $\mathrm{HF}$ or reaction with $\mathrm{Et}_{3} \mathrm{~N} \cdot 3 \mathrm{HF}$. ${ }^{4 d, 44,5 d, 6}$ Oxidative addition of organofluoro compounds via C-F bond activation can be performed, but is somewhat limited to group 9-10 metals. ${ }^{7}$ An alternative strategy to access $\mathrm{M}-\mathrm{F}$ compounds consists of halide exchange reactions that can be carried out under relatively mild reaction conditions, using reagents such as $\mathrm{CsF}^{4 c-d} \mathrm{AgF}^{4 \mathrm{t}}$ $\mathrm{NMe}_{4} \mathrm{~F}^{3 \mathrm{~h}, 4 \mathrm{~g}}$ and $\left[\left(\mathrm{Me}_{2} \mathrm{~N}\right)_{3} \mathrm{~S}\right]^{+}\left[\mathrm{Me}_{3} \mathrm{SiF}_{2}\right]^{-}$(TASF). ${ }^{4 h}$ Such synthetic methods have been applied to ruthenium, leading to fluoride complexes as shown in Figure 1. Caulton and co-workers have reported the synthesis of $\left[\mathrm{Ru}(\mathrm{F})(\mathrm{H})(\mathrm{CO})\left(\mathrm{P}^{t} \mathrm{Bu}_{2} \mathrm{Me}\right)_{2}\right]$ through halide exchange reactions using CsF. ${ }^{4 \mathrm{C}}$ More recently, Whittlesey and coworkers have shown that complexes of type $\left[R u(F)(H)(C O) L_{n}\right]\left(n=2,3 ; L=P_{3}, N H C\right)$ could be isolated using $\mathrm{Et}_{3} \mathrm{~N} \cdot 3 \mathrm{HF}$ as the fluorinating agent. ${ }^{8}$ In all complexes reported by Caulton and Whittlesey, a square pyramidal or an octahedral geometry is adopted with the fluoride ligand trans to the $\pi$-acceptor $\mathrm{CO}$ (Figure 1). A push-pull interaction between the fluoride (here acting as a $\pi$-donor) and the trans carbonyl ligand is invoked to stabilize the Ru-F bond.
Difluoride Ru clusters such as $\left[\mathrm{RuF}_{2}(\mathrm{CO})_{3}\right]_{4}{ }^{5 i-k}$ developed by Wilson and co-workers, and derivatives obtained by substitution of carbonyls with phosphines ${ }^{5 t}$ and $N$ heterocyclic carbenes $(\mathrm{NHC})^{5 \mathrm{~h}}$ were reported by Hope and co-workers. The reactivity of the $18 \mathrm{e}^{-}$-difluoride complexes $\left[\operatorname{RuF}_{2}(\mathrm{CO})_{2} \mathrm{~L}_{2}\right]\left(\mathrm{L}=\mathrm{PR}_{3}, \mathrm{NHC}\right)$ toward Lewis acids (LA) e.g. $\mathrm{PF}_{5}, \mathrm{BF}_{3}$ and $\mathrm{B}\left(\mathrm{C}_{6} \mathrm{~F}_{5}\right)_{3}$ led to the corresponding $16 \mathrm{e}^{-}$-cationic species, where the counterion has a stabilizing effect on the complex ${ }^{5 g-h}$ All reports on Ru-carbonyl complexes contrast with the cationic monofluoride and the neutral difluoride species developed by Mezzetti and co-workers (Figure 1). ${ }^{3 \text {-h }}$

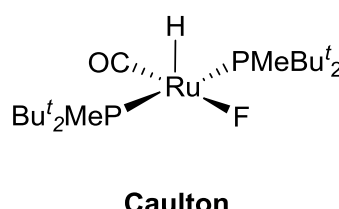

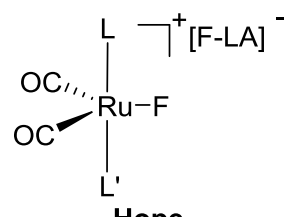

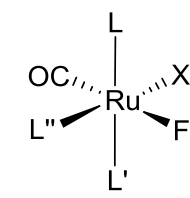

Whittlesey

$L^{\prime}=L^{\prime}=L^{\prime \prime}=P R_{3}$ $\mathrm{NHC} ; \mathrm{X}=\mathrm{H}$

Hope $\mathrm{L}=\mathrm{L}^{\prime}=\mathrm{PR}_{3}, \mathrm{NHC}$ $\mathrm{LA}=\mathrm{PF}_{5}, \mathrm{BF}_{3}, \mathrm{~B}\left(\mathrm{C}_{6} \mathrm{~F}_{5}\right)_{3}$

$\mathrm{L}=\mathrm{L}^{\prime}=\mathrm{PR}_{3}, \mathrm{NHC}$

$L^{\prime \prime}=\mathrm{CO} ; \mathrm{X}=\mathrm{F}, \mathrm{CO}$

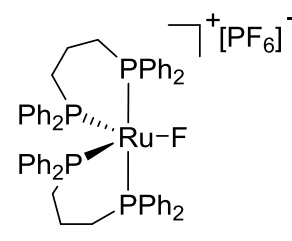

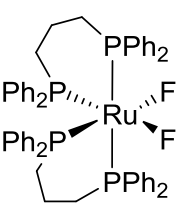

Mezzetti

Figure 1. Ruthenium fluoride complexes. 
This last cationic complex was obtained through halide exchange of $\left[\mathrm{RuCl}(\mathrm{dppp})_{2}\right] \mathrm{PF}_{6}$ with TIF $(\mathrm{dppp}=1,3-$ bis(diphenylphosphino)propane), and further reacted with $\mathrm{NMe}_{4} \mathrm{~F}$ to yield the neutral difluoride species. In these complexes, the fluoride ligand is described as a poor $\pi$-donor ligand, resulting in a simple electrostatic interaction between a cationic ruthenium species and fluoride. To the best of our knowledge, no other type of $\mathrm{Ru}$ complex bearing a $\mathrm{F}$ ligand has been reported to date. Complexes that would be of great interest would be Ru-F containing congeners of alkene metathesis active systems. Indeed, kinetic studies by Grubbs and coworkers showed that the catalytic activity of complexes of the type $\left[\mathrm{RuX}_{2}(\mathrm{SIMes})(=\mathrm{CHPh})\right](\mathrm{X}=\mathrm{Cl}, \mathrm{Br}$, I, SIMes = $N, \quad \quad$ '-bis[2,4,6-(trimethyl)phenyl]imidazolidin-2-ylidene) decreases in the order $\mathrm{Cl}>\mathrm{Br}>\mathrm{I}$, suggesting a possibly higher efficiency for the fluoride analogues. ${ }^{9}$ Computational studies on the formation of ruthena(IV)cyclobutanes from $1^{\text {st }}$ and $2^{\text {nd }}$ generation Grubbs pre-catalysts and norborn-2-ene have illustrated a similar trend of reactivity for dihalides complexes $(\mathrm{F}>\mathrm{Cl}>\mathrm{Br}>$ I), predicting the best activity of difluoride species among olefin metathesis pre-catalysts. ${ }^{10}$ Despite this insight into possible reactivity, whereas bromide/iodide/carboxylate versions of Grubbs and Hoveyda-Grubbs type complexes have been extensively studied, ${ }^{9,11}$ no fluoride version has, to the best of our knowledge, been reported to date. A few failed attempts using $\mathrm{HF}$ or $\mathrm{AgF}$ suggest that these methodologies or Grubbs/Hoveyda-Grubbs type complexes are not suitable for the synthesis of Ru-F species for olefin metathesis. ${ }^{12}$ Recently, we have developed a new class of Ru-olefin metathesis catalysts that displays an unusual cis-geometry and leads to outstanding stability and activity in olefin metathesis reactions. ${ }^{13}$ It appeared therefore of great interest to evaluate the ability of such complexes to undergo chloride exchange with fluoride. Herein, we report our findings on chloride exchange reactions using a number of olefin metathesis pre-catalysts.

\section{Results and Discussion}

Chloride exchange with AgF. The reactivity of various commercially available pre-catalysts with $\mathrm{AgF}$ as a fluoride source was initially examined (Figure 2 ).

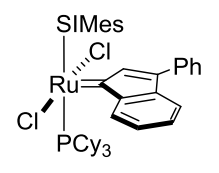

Ind-II

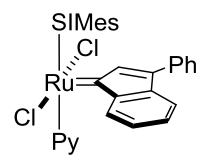

Ind-III

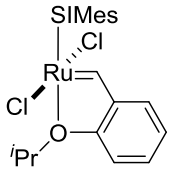

Hov-II

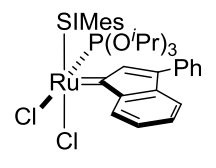

cis-Caz-1
Figure 2. Olefin metathesis pre-catalysts tested in $\mathrm{Cl}$ exchange.

The reaction of Ind-II, Ind-III and Hov-II with $\mathrm{AgF}$ showed no conversion of the starting material after $1 \mathrm{~h}$ (Table 1, entries 1-3). In contrast, under the same reaction conditions, the phosphite-containing complex transCaz-1 leads to $10 \%$ conversion of the starting material into the mono-fluorinated species (Table 1, entry 4). With longer reaction time $(24 \mathrm{~h}), 53 \%$ of trans-Caz-1 was converted into a Ru-F species (Table 1, entry 5). Monitoring this reaction for a few hours showed a reaction- rate similar to the one involved in the trans-cis isomerization of the complex. ${ }^{14}$ We therefore reasoned that isomerization might be required before chloride exchange. If such were the case, the cis-complex should show a superior reactivity. Cis-Caz-1 was thus reacted with AgF. A very rapid reaction occurred with a $76 \%$ conversion leading to the same fluorinated product obtained from trans-Caz-1 (Table 1, entry 6). Using 2 equivalents of $\mathrm{AgF}$, full conversion of the starting material was observed with both mono- and difluoride products formed. Using only $20 \%$ excess of $\mathrm{AgF}$ leads to the selective formation of the mono-fluorinated product (Table 1, entries 7 and 8). Increasing the amount of $\mathrm{AgF}$ to 2.4 equivalents leads to the quantitative formation of the difluoride species (Table 1, entry 9).

\section{Table 1. Chloride exchange with AgF. ${ }^{a}$}

\begin{tabular}{|c|c|c|c|c|c|}
\hline \multicolumn{2}{|c|}{$[\mathrm{Ru}] \mathrm{Cl}_{2}+\mathrm{nAgF}$} & \multicolumn{2}{|c|}{$\mathrm{CD}_{2} \mathrm{Cl}_{2}, \mathrm{rt}, 1 \mathrm{~h}$} & $\mathrm{Ru}] \mathrm{Cl}_{2-n} \mathrm{~F}_{\mathrm{n}}$ & $\mathrm{nAgCl}$ \\
\hline Entry & Pre-catalyst & $\begin{array}{c}\text { AgF } \\
\text { equiv. }\end{array}$ & $\begin{array}{l}{[\mathrm{Ru}] \mathrm{Cl}_{2}} \\
\text { species }^{b}\end{array}$ & $\begin{array}{l}{[\mathrm{Ru}] \mathrm{CIF}} \\
\text { species }^{b}\end{array}$ & $\begin{array}{c}{[\mathrm{Ru}] \mathrm{F}_{2}} \\
\text { species }^{b}\end{array}$ \\
\hline 1 & Ind-II & 1 & 100 & n.r. & n.r. \\
\hline 2 & Ind-III & 1 & 100 & n.r. & n.r. \\
\hline 3 & Hov-II & 1 & 100 & n.r. & n.r. \\
\hline 4 & trans-Caz-1 & 1 & 90 & 10 & - \\
\hline 5 & trans-Caz-1 & 1 & $47^{c}$ & $53^{c}$ & - \\
\hline 6 & cis-Caz-1 & 1 & 24 & 76 & - \\
\hline 7 & cis-Caz-1 & 1.2 & - & $>99$ & - \\
\hline 8 & cis-Caz-1 & 2 & - & 21 & 79 \\
\hline 9 & cis-Caz-1 & 2.4 & - & - & $>99$ \\
\hline
\end{tabular}

${ }^{a}$ Reaction conditions: Complex (0.01 mmol), AgF (1-2.4 equiv.), $\mathrm{CD}_{2} \mathrm{Cl}_{2}(0.6 \mathrm{~mL}), \mathrm{rt}, 1 \mathrm{~h}$. ${ }^{b}$ Conversion (\%) determined by ${ }^{1} \mathrm{H}$ NMR. ${ }^{2} 24 \mathrm{~h}$.

Synthesis of $\left[\mathrm{Ru}(\mathrm{Cl})(\mathrm{F})(\mathrm{Ind})(\mathrm{SIMes})\left\{\mathrm{P}\left(\mathrm{O}^{\prime} \mathrm{Pr}\right)_{3}\right\}\right]$, Caz$\mathbf{1}_{\mathrm{F}}$. Caz-1 $\mathbf{1}_{\mathrm{F}}$ was quantitatively obtained by reaction of 1 equivalent of cis-Caz-1 with 1.2 equivalents of $\mathrm{AgF}$. The ${ }^{1} \mathrm{H}$ NMR spectrum contains a characteristic doublet at $8.93 \mathrm{ppm}$ assigned to the indenylidene (Ind) $\mathrm{H}^{7}$ proton, which is shifted downfield compared to the signal observed for cis-Caz-1. In the ${ }^{31} \mathrm{P}-\left\{{ }^{1} \mathrm{H}\right\}$ NMR spectrum, a doublet is observed at $131.4 \mathrm{ppm}\left({ }^{2} J_{\mathrm{PF}}=286 \mathrm{~Hz}\right)$, corresponding to the phosphite ligand. This signal is also shifted downfield compared to the ${ }^{31} \mathrm{P}$ signal of the starting material. ${ }^{13 a}$ In the ${ }^{19} \mathrm{~F}-\left\{{ }^{1} \mathrm{H}\right\}$ NMR spectrum, a doublet at $-217.2 \mathrm{ppm}\left({ }^{2} J_{\mathrm{PF}}=286 \mathrm{~Hz}\right)$ is found. These data are consistent with a trans disposition of the fluorine and phosphite ligands. The ${ }^{13} \mathrm{C}-\left\{{ }^{1} \mathrm{H}\right\}$ NMR spectrum contains a doublet at $289.6 \mathrm{ppm}\left({ }^{2} J_{\mathrm{CP}}=25.5 \mathrm{~Hz}\right)$ and a doublet at $209.1 \mathrm{ppm}\left({ }^{2} J_{\mathrm{CP}}=16.0 \mathrm{~Hz}\right)$ corresponding to the carbene carbon atom of the indenylidene and of the $N$ heterocyclic carbene, respectively. The structure was unambiguously confirmed by single crystal X-ray diffraction (Figure 3). ${ }^{15}$

Caz-1 $\mathbf{1}_{\mathrm{F}}$ presents a slightly distorted square pyramidal geometry with the indenylidene unit sitting at the apical position. Hydrogen bonding (dashed line) between $\mathrm{H}^{7}$ of the indenylidene ring and the fluorine atom is observed, which might explain the smaller $\mathrm{C}_{\text {Ind }}-\mathrm{Ru}-\mathrm{F}$ angle $\left(102.82(13)^{\circ}\right)$ observed compared to the dichloride analogue $\left(104.3(2)^{\circ}\right) .^{13 a}$ Similar intramolecular $\mathrm{F} \cdots \mathrm{H}$ interac- 
tions have also been observed by Hope and coworkers. ${ }^{5 f}$

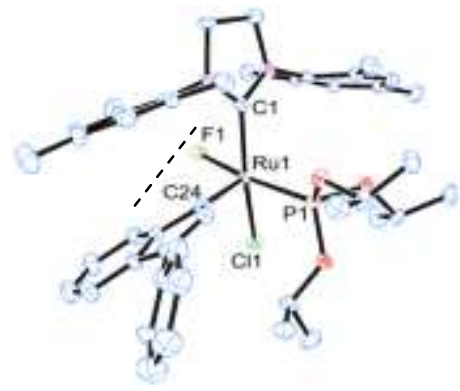

Figure 3. Molecular structure of Caz-1 $\mathbf{F}_{\mathrm{F}}$. All solvent molecules and hydrogen atoms are omitted for clarity. Thermal ellipsoids are shown at the $50 \%$ probability level.

Synthesis of $\left[\mathrm{RuF}_{2}(\mathrm{Ind})(\mathrm{SIMes})\left\{\mathrm{P}\left(\mathrm{O}^{\prime} \mathrm{Pr}\right)_{3}\right\}\right], \mathrm{Caz} \mathbf{1}_{\mathrm{F} 2}$. The difluorinated complex Caz-1 $\mathbf{F}_{\mathbf{F}}$ was quantitatively obtained by reaction of cis-Caz-1 with 2.4 equivalents of AgF. The ${ }^{1} \mathrm{H}$ NMR spectrum contains a characteristic doublet at $9.02 \mathrm{ppm}$ corresponding to the indenylidene $\mathrm{H}^{7}$ proton, which is shifted downfield compared to Caz-1 $\mathbf{1}_{\mathrm{F}}$ (8.93 ppm) and cis-Caz-1 (8.87 ppm). ${ }^{13 a}$ In the ${ }^{31} \mathrm{P}-\left\{{ }^{1} \mathrm{H}\right\}$ NMR spectrum, a doublet at $131.5 \mathrm{ppm}\left({ }^{2} J_{\mathrm{PF}}\right.$ of $\left.286 \mathrm{~Hz}\right)$ corresponding to the phosphite ligand is observed. This signal is also shifted downfield compared to the ${ }^{31} \mathrm{P}$ signal of Caz-1 $\mathbf{F}_{\mathrm{F}}$ and cis-Caz-1. ${ }^{13 a}$ The ${ }^{19} \mathrm{~F}-\left\{{ }^{1} \mathrm{H}\right\}$ NMR spectrum contains a doublet at $-217.7 \mathrm{ppm}\left({ }^{2} J_{\mathrm{PF}}=286 \mathrm{~Hz}\right)$ corresponding to the fluoride trans to the phosphite, and a broad singlet at $-237.2 \mathrm{ppm}$ corresponding to the second fluoride, which is cis to the phosphite ligand. The ${ }^{13} \mathrm{C}-\left\{{ }^{1} \mathrm{H}\right\}$ NMR was recorded at $223 \mathrm{~K}$. The spectrum contains two broad signals at $287.0 \mathrm{ppm}$ and $211.1 \mathrm{ppm}$ corresponding to the carbene carbon atom of the indenylidene and of the $\mathrm{N}$-heterocyclic carbene, respectively. The structure of the complex was confirmed by Xray diffraction on single crystal (Figure 4). ${ }^{16} \mathrm{~A}$ similar interaction (dashed line) between $\mathrm{H}^{3}$ of indenylidene ring and the fluorine atom trans to the phosphite is observed, presumably responsible for the relatively small $C_{\text {Ind }}-R u-F$ angle $\left(103.39(17)^{\circ}\right)$ compared to the dichloride analogue $\left(104.3(2)^{\circ}\right) .{ }^{13 a}$ Both complexes display a distorted square pyramidal geometry with the phosphite ligand cis to the $\mathrm{NHC} \quad\left(\mathrm{P}-\mathrm{Ru}-\mathrm{C}_{\mathrm{NHC}}\right.$ angles being $97.66(10)^{\circ}$ and 97.82(14) ${ }^{\circ}$ for Caz-1 $_{\mathbf{F}}$ and Caz-1 $\mathbf{1}_{\mathbf{F} 2}$, respectively) (Table 2).

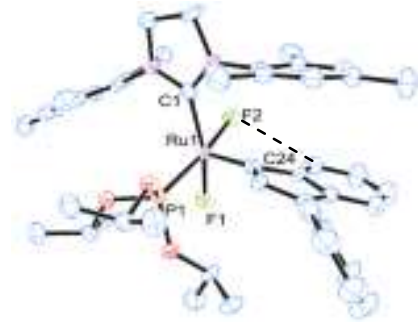

Figure 4. Molecular structure of $\mathbf{C a z}-\mathbf{1}_{\mathrm{F2}}$. All solvent molecules and hydrogen atoms are omitted for clarity. Thermal ellipsoids are shown at the $50 \%$ probability level.
In both complexes, the Ru-F bond is significantly shorter than the Ru-Cl. For all complexes, comparable Ru-C (NHC and indenylidene) bond lengths are found, while Ru-P bond distances show some disparity. The latter decreases in the following order: cis-Caz-1 $>$ Caz-1 ${ }_{\mathrm{F}}>\mathbf{C a z}-$ $\mathbf{1}_{\mathrm{F} 2}$, which reflects the electronegativity of $\mathrm{F} v s \mathrm{Cl}$.

Table 2. Selected bond distances $(\AA)$, angles $\left({ }^{\circ}\right)($ esd).

\begin{tabular}{llll} 
& \multicolumn{1}{c}{} \\
& $2.4036(18)$ & $2.029(3)$ & $2.017(3)$ \\
\hline $\mathrm{Ru}(1)-\mathrm{X}_{\text {transP }}$ & $2.3974(19)$ & $2.3837(12)$ & $2.035(4)$ \\
$\mathrm{Ru}(1)-\mathrm{X}_{\text {trans } \mathrm{NHC}}$ & $2.249(2)$ & $2.2426(11)$ & $2.2263(16)$ \\
$\mathrm{Ru}(1)-\mathrm{P}(1)$ & $2.067(7)$ & $2.059(4)$ & $2.053(6)$ \\
$\mathrm{Ru}(1)-\mathrm{C}(24)$ & $1.881(8)$ & $1.864(5)$ & $1.846(6)$ \\
$\mathrm{Ru}(1)-\mathrm{C}(1)$ & $100.6(19)$ & $97.66(10)$ & $97.82(14)$ \\
$\mathrm{P}(1)-\mathrm{Ru}(1)-\mathrm{C}(24)$ & & \\
$\mathrm{P}(1)-\mathrm{Ru}(1)-\mathrm{C}(1)$ & $90.5(2)$ & $90.19(12)$ & $89.95(15)$ \\
$\mathrm{C}(24)-\mathrm{Ru}(1)-\mathrm{C}(1)$ & $98.7(3)$ & $97.09(17)$ & $96.1(3)$ \\
\hline
\end{tabular}

Chloride exchange and isomerization studies. Braddock and co-workers have reported a study using Hoveyda-Grubbs pre-catalysts of the type $\left[R u X_{2}\right.$ (SIMes) $\left.\left(=\mathrm{CH}-2-\left({ }^{\prime} \mathrm{PrO}\right)-\mathrm{C}_{6} \mathrm{H}_{4}\right)\right]$ where $\mathrm{X}$ is $\mathrm{Cl}, \mathrm{Br}$, $\mathrm{CF}_{3} \mathrm{CO}_{2}$ and $\mathrm{C}_{2} \mathrm{~F}_{5} \mathrm{CO}_{2} .{ }^{11 \mathrm{~d}}$ When reacting two complexes containing different pairs of anionic ligands (1:1 molar ratio), a statistical mixture of 1:2:1 was obtained, where a novel complex with mixed anions is in equilibrium with the starting materials (pseudodegenerate ligand exchange). ${ }^{11 d}$ This encouraged us to investigate the ability of our dichloro and difluoro-species to be involved in such an exchange (Table 3 ).

Table 3. Fluoride exchange reactions.

\begin{tabular}{|c|c|c|c|}
\hline & ${ }_{\mathrm{Caz}-1}$ & $-2 \underset{\mathrm{Fl}^{\prime \prime \prime \prime}}{\mathrm{Ph}}$ & $\begin{array}{l}\text { SIMes } \\
-\mathbf{1}_{\mathrm{F}}\left(\mathrm{O}^{\prime} \mathrm{Pr}\right)_{3}\end{array}$ \\
\hline Entry & Complex & Time (h) & $\begin{array}{c}\text { Conversion to } \\
\text { Caz-1 }_{\mathrm{F}}(\%)^{a}\end{array}$ \\
\hline 1 & $\mathrm{Caz}-1_{\mathrm{F} 2}+$ cis-Caz-1 & 0.5 & $>99$ \\
\hline $\begin{array}{l}2 \\
3 \\
4\end{array}$ & Caz-1 $1_{\mathrm{F} 2}+$ trans-Caz-1 & $\begin{array}{l}0.5 \\
1.5 \\
24\end{array}$ & $\begin{array}{c}30 \\
40 \\
>99\end{array}$ \\
\hline
\end{tabular}

${ }^{a}$ Determined by ${ }^{1} \mathrm{H}$ NMR.

When the dichloride species cis-Caz-1 was mixed with Caz-1 $_{\mathbf{F 2}}$, rapid and quantitative reaction was observed, with the mono-fluorinated compound being the only product formed (Table 3, entry 1), which is in marked contrast with the Braddock findings. Furthermore, complete fluorination of trans-Caz-1 can be achieved, requiring longer reaction time (Table 3 , entry 4 ). This is of great interest considering that the formation of this compound from trans-Caz-1 was found problematic when 
using the AgF-promoted $\mathrm{Cl}$ exchange route (Table 1, entries 4 and 5 ). In addition, comparison of the rate of isomerization of trans-Caz-1 to cis-Caz-1 with the rate of fluorination of trans-Caz-1 by $\mathbf{C a z}-\mathbf{1}_{\mathrm{F} 2}$ showed that the latter process is faster, which is again in contrast with the results obtained with $\mathrm{AgF} .^{17}$ These results prompted us to investigate the fluorination of Ind-II, Ind-III and Hov-II using $\mathbf{C a z}_{\mathbf{F}}$. Unfortunately, no selective formation of fluorinated compounds was observed in these instances. $^{18}$

Computational Studies. Insights into the stability of the $\mathrm{Ru}$ complexes isolated in this work and their corresponding trans-species were obtained using a computational DFT approach (Table 4). ${ }^{19}$ As can be seen in Table 4, the energy values are clearly affected by the relative stability of the free chloride and free fluoride anions in solution.

Table 4. Energetics (kcal/mol) of the chloride exchange reactions.

\begin{tabular}{|c|c|c|c|}
\hline Caz-1 + 2F & \multicolumn{2}{|c|}{$-\mathrm{Caz}_{-1} \mathbf{F}+\mathrm{F}^{-}+\mathrm{Cl}^{-}$} & $\mathrm{az}-1_{\mathrm{F} 2}+2 \mathrm{Cl}^{-}$ \\
\hline Isomer & Caz-1 + 2F & $\mathrm{Caz}_{\mathrm{F}}+\mathrm{F}^{-}+\mathrm{Cl}$ & $\mathrm{Caz} \mathbf{1}_{\mathrm{F} 2}+2 \mathrm{Cl}$ \\
\hline cis & 0.0 & -18.9 & -32.6 \\
\hline trans & +6.8 & -7.3 & -17.9 \\
\hline trans - cis & +6.8 & +11.6 & +14.7 \\
\hline
\end{tabular}

Focusing on the cis complexes, the replacement of one chloride ligand of cis-Caz-1 by one fluoride ligand, leading to $\mathbf{C a z}-1_{\mathrm{F}}+\mathrm{Cl}^{-}$, is favored by $18.9 \mathrm{kcal} / \mathrm{mol}$ (Table 4). In agreement with the experiments, the most stable isomer of $\mathbf{C a z}-\mathbf{1}_{\mathrm{F}}$ presents the fluoride ligand trans to the $\mathrm{P}\left(\mathrm{O}^{\prime} \mathrm{Pr}\right)_{3}$ ligand. The isomer with the fluoride ligand trans to the $\mathrm{NHC}$ ligand is $11.6 \mathrm{kcal} / \mathrm{mol}$ higher in energy. Substitution of the second chloride atom in the trans isomer, i.e. the one with the $\mathrm{P}\left(\mathrm{O}^{\prime} \mathrm{Pr}\right)_{3}$ ligand trans to the $\mathrm{NHC}$ ligand, is less favored than the substitution of the second chloride in the cis isomer (see Table 4). However, it is worth noting that in Caz-1 the cis isomer is only $6.8 \mathrm{kcal} / \mathrm{mol}$ more stable than the trans isomer, while in $\mathrm{Caz}_{\mathrm{F}}$ and $\mathbf{C a z}-\mathbf{1}_{\mathrm{F} 2}$ this preference increases to 11.6 and $14.7 \mathrm{kcal} / \mathrm{mol}$, respectively. Finally, combination of the energy values of the three cis species in Table 4 indicates that the formation of 2 mol of Caz-1 $\mathbf{F}_{\mathrm{F}}$ by mixing 1 mol of cis-Caz-1 and 1 mol of Caz-1 $\mathbf{F}_{\mathbf{F} 2}$ is favored by 5.2 $\mathrm{kcal} / \mathrm{mol}$. Overall, these results are consistent with the experimental data showing that when cis-Caz-1 is reacted with 1 equivalent of $\mathrm{AgF}$, only $\mathrm{Caz}_{-1} \mathbf{1}_{\mathrm{F}}$ is formed, and when cis-Caz-1 is reacted with cis-Caz-1 $\mathbf{1}_{\mathrm{F} 2}$ only Caz-1 $\mathbf{1}_{\mathrm{F}}$ is still obtained. A better understanding of the relative strength of the different Ru-halide bonds in these systems was achieved with bond snapping energy calculations (BSE) which is the energy required for the dissociation of the Ru-X bond (see Table 5). In these calculations the geometry of the $[\mathrm{Ru}]$ fragment is kept rigid, and we calculated both homolytic and heterolytic BSEs, which means fragmenting the complex into radical and neutral $[R u] \bullet$ and $X \bullet$ fragments, or into cationic $[R u]^{+}$and anionic $X^{-}$fragments, respectively. The BSEs in Table 5 indicate that all the Ru-F BSEs are stronger than the BSE for the corresponding $\mathrm{Ru}-\mathrm{Cl}$ bond, independently from homo or heterolytic fragmentation of the complexes. This allows us to conclude that the Ru-F bond is stronger than the corresponding $\mathrm{Ru}-\mathrm{Cl}$ bond. More specifically, the data reported in Table 5 clearly indicate that the Ru$\mathrm{F}$ bonds in cis-Caz-1 $\mathbf{F}_{\mathrm{F} 2}$ are roughly $12-18 \mathrm{kcal} / \mathrm{mol}$ stronger than the corresponding $\mathrm{Ru}-\mathrm{Cl}$ bonds in cis-Caz1. Moreover, for the same complexes, the Ru-halide bond trans to the $\mathrm{P}\left(\mathrm{O}^{\prime} \mathrm{Pr}\right)_{3}$ ligand is from 3 to $10 \mathrm{kcal} / \mathrm{mol}$ weaker than the Ru-halide bond trans to the $\mathrm{NHC}$ ligand (comparing entries 9 and 10 as well as entries 1 and 2 in Table 5), suggesting that it is the Ru-halide bond trans to the $P$ atom that undergoes dissociation. Focusing on cis$\mathrm{Caz}_{\mathrm{F}}$, the Ru-Cl bond is weaker than the Ru-F bond, comparing entries 3 and 4 in Table 5, despite the chloride ligand being trans to the NHC ligand. Finally, the strength of the Ru-Cl bond trans to the NHC ligand is nearly the same in cis-Caz-1 and cis-Caz-1 $\mathbf{1}_{\mathrm{F}}$, comparing entries 1 and 3 in Table 5. Focusing on trans-Caz-1, in agreement with our previous work, ${ }^{20}$ calculations indicate that the $\mathrm{Ru}-\mathrm{Cl}$ bond is stronger when it is trans to another $\mathrm{Cl}$ atom rather than to a $\mathrm{P}$ atom, comparing entries 2 and 5 in Table 5.

Table 5. $\mathrm{Ru}-\mathrm{X}$ bond snapping energy (BSE) in $\mathrm{CH}_{2} \mathrm{Cl}_{2}$ (kcal $/ \mathrm{mol}$ ).

\begin{tabular}{|c|c|c|c|c|}
\hline & Pre-catalyst & Atom & $\begin{array}{c}\text { Heterolytic } \\
\text { BSE }\end{array}$ & $\begin{array}{c}\text { Homolytic } \\
\text { BSE }\end{array}$ \\
\hline 1 & cis-Caz-1 & $\begin{array}{l}\mathrm{Cl} \text { trans to } \\
\mathrm{NHC}\end{array}$ & 31.5 & 79.0 \\
\hline 2 & cis-Caz-1 & $\mathrm{Cl}$ trans to $\mathrm{P}$ & 21.7 & 84.3 \\
\hline 3 & cis-Caz-1 $1_{F}$ & $\begin{array}{c}\mathrm{Cl} \text { trans to } \\
\mathrm{NHC}\end{array}$ & 30.9 & 85.1 \\
\hline 4 & cis-Caz-1 ${ }_{F}$ & $\mathrm{~F}$ trans to $\mathrm{P}$ & 40.6 & 110.4 \\
\hline 5 & trans-Caz-1 & equivalent $\mathrm{Cl}$ & 36.0 & 92.8 \\
\hline 6 & trans-Caz-1 $1_{\mathrm{F} 2}$ & equivalent $\mathrm{F}$ & 47.5 & 116.1 \\
\hline 7 & trans-Caz-1 $\mathbf{1}_{\mathrm{F}}$ & $\mathrm{F}$ trans to $\mathrm{Cl}$ & 47.2 & 114.1 \\
\hline 8 & trans-Caz-1 $\mathbf{1}_{\mathrm{F}}$ & $\mathrm{Cl}$ trans to $\mathrm{F}$ & 37.4 & 97.2 \\
\hline 9 & cis-Caz-1 $1_{\mathrm{F} 2}$ & $\mathrm{~F}$ trans to $\mathrm{NHC}$ & 43.5 & 110.2 \\
\hline 10 & cis-Caz-1 $1_{\mathrm{F} 2}$ & $\mathrm{~F}$ trans to $\mathrm{P}$ & 40.3 & 113.7 \\
\hline
\end{tabular}

To gauge if the increased strength of the Ru-F bond relative to the $\mathrm{Ru}-\mathrm{Cl}$ bond is electrostatic in nature or is due to increased back-donation from the $F$ ligand to the $\mathrm{Ru}$ center through a push-pull effect induced by the $\pi$-acid phosphite, we performed an energy decomposition analysis (EDA) of the Ru-X bond in cis-Caz-1 and cis-Caz$\mathbf{1}_{\mathbf{F} 2}$ (see Table 6). We briefly remind the reader that the total BSE can be decomposed into three main terms, $\mathrm{BSE}=E_{\mathrm{El}}+E_{\mathrm{Pauli}}+E_{\mathrm{Orb}}$. $E_{\mathrm{El}}$ accounts for stabilizing electrostatic interaction between the two fragments, $E_{\text {pauli }}$ accounts for repulsion between doubly filled molecular orbitals on the two fragments, and $E_{\text {Orb }}$ accounts for stabilizing interaction between filled orbitals on one fragment with empty orbitals on the other fragment. Since the EDA is performed on the intrinsic strength of the Ru-X bond, which does not depend on the environment that can only stabilize the two fragments, the EDA is performed in the gas-phase. Focusing on cis-Caz-1 and cis-Caz-1 $\mathbf{1}_{\mathbf{F} 2}$, the data reported in Table 6 indicate that the increased strength of the Ru-F bond in cis-Caz-1 $\mathbf{F}_{\mathbf{F}}$ compared to the $\mathrm{Ru}-\mathrm{Cl}$ bond in cis-Caz-1 is almost $50 \%-50 \%$ shared between the orbital and the electrostatic terms, since both are roughly $14-15 \mathrm{kcal} / \mathrm{mol}$ stronger in $\mathrm{cis}-\mathrm{Caz}_{\mathbf{F}} \mathbf{- 1} \mathrm{Com}-$ 
pared to cis-Caz-1. None of the two terms is clearly dominant. The repulsive Pauli term is instead rather similar. This suggests that the increased strength of the Ru-F bond is equally a consequence of an increased ionic character of the bond, due to the higher electronegativity of the $\mathrm{F}$ atom, and of an increased orbital interaction, that can be probably correlated to back-donation from the $\mathrm{F}$ ligand to the Ru center through a push-pull effect. Comparison between cis-Caz-1 $\mathbf{1}_{\mathbf{F} 2}$ and cis-Caz-1 $\mathbf{1}_{\mathbf{F}}$ indicates that the halide trans to the NHC ligand has a small impact on the Ru-F bond trans to the phosphite.

Table 6. Decomposition analysis of the bond snapping energy of selected Ru-X bonds in the gasphase. The total bond snapping energy is decomposed as: $-\mathrm{BSE}=E_{\mathrm{El}}+E_{\mathrm{Pauli}}+E_{\mathrm{Orb}}$. All values in $\mathrm{kcal} / \mathrm{mol}$.

\begin{tabular}{ccccc}
\hline & $\mathrm{E}_{\mathrm{EI}}$ & $\mathrm{E}_{\mathrm{Pauli}}$ & $\mathrm{E}_{\mathrm{Orb}}$ & $-\mathrm{BSE}$ \\
\hline cis-Caz-1 & -154.7 & 117.5 & -77.9 & -115.0 \\
cis-Caz-1 $_{\mathrm{F} 2}$ & -168.3 & 122.7 & -92.6 & -138.1 \\
cis-Caz-1 $_{\mathrm{F}}$ & -168.0 & 119.2 & -94.0 & -142.8 \\
\hline
\end{tabular}

Catalytic studies in ring-closing metathesis (RCM). The catalytic activities of both $\mathbf{C a z}-\mathbf{1}_{\mathrm{F} 2}$ and $\mathbf{C a z}-\mathbf{1}_{\mathrm{F}}$ were first examined in the ring-closing metathesis (RCM) of the challenging substrate N,N-bis(2methylallyl)tosylamide 1, and compared with the catalytic activity of the dichloro-analogue cis-Caz-1. As thermal activation is required to efficiently promote such a reaction, a first comparative study at different temperatures was carried out (Figure 5). ${ }^{1,21}$ As can be seen in Figure 5 , while the mono-fluoride performs very well, the difluoride analogue leads to poor conversion to 2 (max. 33\% at $110^{\circ} \mathrm{C}$ ). Comparison of cis-Caz-1 with its monofluoride analogue $\mathrm{Caz}-\mathbf{1}_{\mathrm{F}}$ shows that, while the catalytic activity of the dichloride derivative reaches its maximum at $90^{\circ} \mathrm{C}$ (79\%), the activity of the mono-fluoride derivative carries on increasing with temperature $\left(84 \%\right.$ at $\left.120^{\circ} \mathrm{C}\right)$. This result is even more striking if we compare the catalytic profile of the ring-closing reaction of the three complexes at $110^{\circ} \mathrm{C}$ (Figure 6). Under such conditions, cis-Caz-1 has a rapid rate of reaction, followed by a rapid catalyst deactivation (87\% conversion within $15 \mathrm{~min}$ ) while $\mathbf{C a z}-\mathbf{1}_{\mathrm{F}}$ has an induction period of ca. 3 minutes and reaches $93 \%$ conversion within 40 minutes. On the other hand, the difluoro-species, $\mathbf{C a z}-\mathbf{1}_{\mathbf{F} 2}$, is poorly active under such reaction conditions $(6 \%$ conversion after $2 \mathrm{~h}$, and $21 \%$ after $24 \mathrm{~h}$ ). ${ }^{22}$ It should be noted that cis-Caz-1 outperformed other commercially available pre-catalysts (such as Ind-II, Hov-II and Ind-III) in the RCM of substrate $\mathbf{1}$ under similar conditions, ${ }^{13 a .13 \mathrm{C}}$ thus suggesting that Caz$\mathbf{1}_{\mathrm{F}}$ could be a serious contender for this transformation.

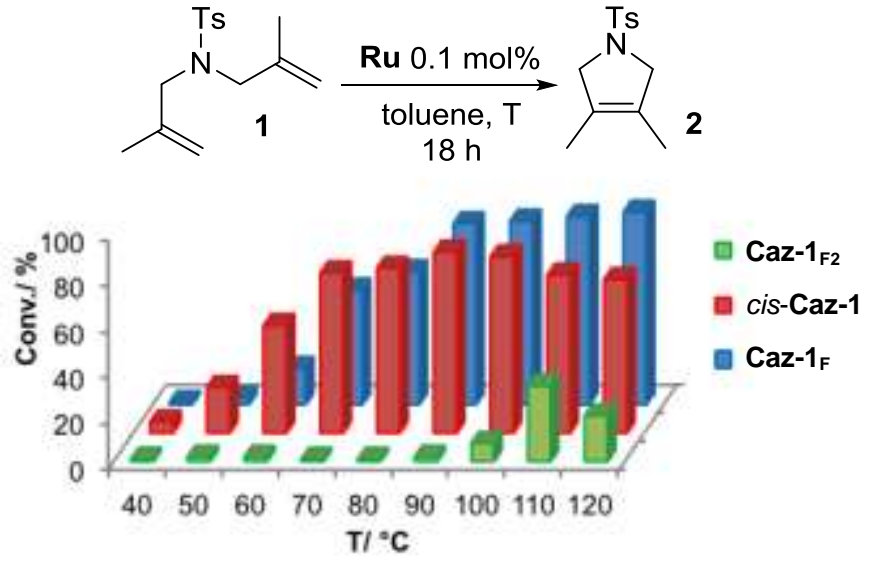

Figure 5. Temperature dependence in the RCM investigated.

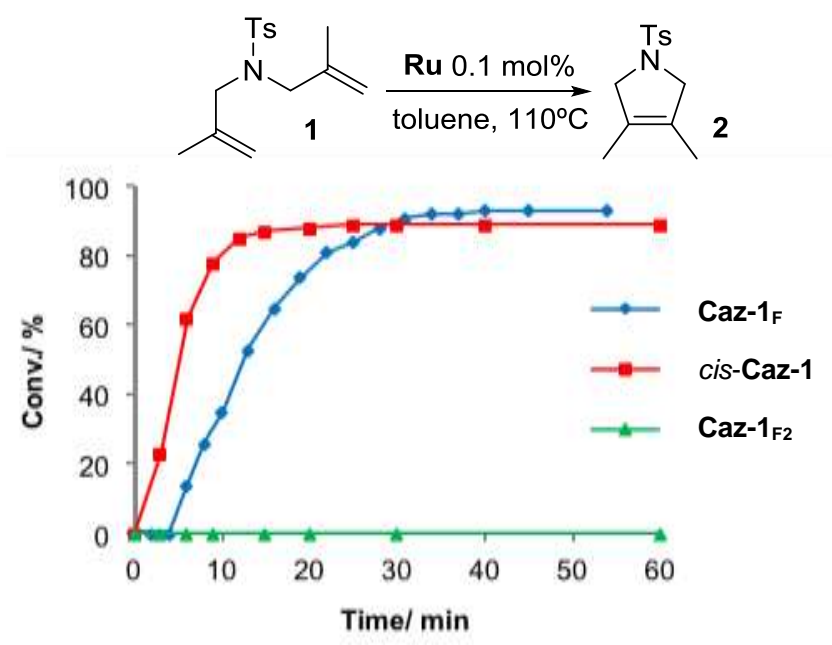

Figure 6. Reaction profiles of cis-Caz-1, Caz-1 $\mathbf{1}_{\mathrm{F}}$ and Caz-1 $1_{F 2}$ in the RCM of 1 (lines are visual aids and not curve fits).

In order to shed light on the formation of the catalytically active species, further DFT calculations were undertaken. For this purpose, we investigated the possible mechanism leading to formation of the classic $14 \mathrm{e}^{-}$intermediate, with the $\mathrm{Ru}$ atom presenting a vacant coordination position trans to the NHC ligand for substrate coordination. Starting from the cis isomers, two mechanisms can be envisaged. The first corresponds to concerted cis to trans isomerization of the complex with the phosphite still coordinated to the Ruthenium, followed by phosphite dissociation. The second corresponds to dissociation of the phosphite from the cis isomer, followed by isomerization of the resulting $14 \mathrm{e}^{-}$intermediate, presenting one halide trans to the NHC ligand, to the most stable $14 \mathrm{e}^{-}$ intermediate with a vacant coordination site trans to the $\mathrm{NHC}$ ligand.

According to calculations, the barrier for the concerted cis-trans isomerization of the phosphite coordinated species is $35.0,42.1$ and $42.3 \mathrm{kcal} / \mathrm{mol}$ for Caz-1, Caz-1 $\mathbf{F}_{\mathrm{F}}$ and $\mathbf{C a z}-\mathbf{1}_{\mathbf{F 2}}$, respectively, leading to the trans isomers at $6.8,11.6$ and $14.7 \mathrm{kcal} / \mathrm{mol}$ above the corresponding cis isomer (see Table 4). To complete this pathway, phos- 
phite dissociation from the trans isomers costs 6.1, 6.0 and $3.9 \mathrm{kcal} / \mathrm{mol}$ (trans-Caz-1, trans-Caz-1 $\mathbf{1}_{\mathrm{F}}$ and transCaz-1 $\mathbf{F}_{\mathbf{F}}$, respectively). As for the step-wise activation mechanism, we were not able to locate a stable geometry for the $14 \mathrm{e}^{-}$intermediate with a halide trans to the $\mathrm{NHC}$ ligand. In all cases, this intermediate collapsed to the most stable geometry with the two halides in trans to each other. This suggests that phosphite dissociation from the cis isomer triggers, and is concerted with, the rearrangement of the Ru moiety to the most stable $14 \mathrm{e}$ intermediate with the vacancy trans to the NHC ligand. We thus located the transition state for this process, and we found barriers of 28.8, 35.8 and 37.1 for Caz-1, Caz$\mathbf{1}_{\mathrm{F}}$ and $\mathbf{C a z}-\mathbf{1}_{\mathrm{F} 2}$, respectively. Comparison between the two mechanisms thus indicates that the most likely mechanism for activation of the cis complexes consists in the dissociation of the phosphite with concerted isomerization of the Ru-moiety to generate the $14 \mathrm{e}^{-}$intermediate with a vacant coordination position trans to the $R u$ atom. Furthermore, the trend in the energy of the transition states for phosphite dissociation from the cis complexes, easier for Caz-1 and more difficult for $\mathbf{C a z}_{\mathbf{F}} \mathbf{1}_{\mathbf{F}}$, is consistent with the trend observed for the metathesis activity of Figures 5 and 6 . As a remark, we note that we are somewhat overestimating the barrier for phosphite dissociation for $\mathrm{Caz}_{\mathrm{F}}$, which should be closer to the barrier calculated for Caz-1.

Finally, the beneficial effect of using a fluorinated aromatic solvent was examined for all three complexes (Figure 7). As previously suggested by DFT calculations, ${ }^{23}$ an aromatic solvent molecule can stabilize the $14 \mathrm{e}^{-}$species by direct coordination to the Ru center. The same calculations indicated that fluorinated aromatic solvent molecules interact remarkably more strongly than their non-fluorinated counterpart, and this result was correlated to the higher catalytic activity of $\mathrm{Ru}$ catalysts in olefin metathesis. This is consistent with the results depicted in Figure 7, as in all cases, catalytic activity is improved when the reaction is carried out in perfluorotoluene.
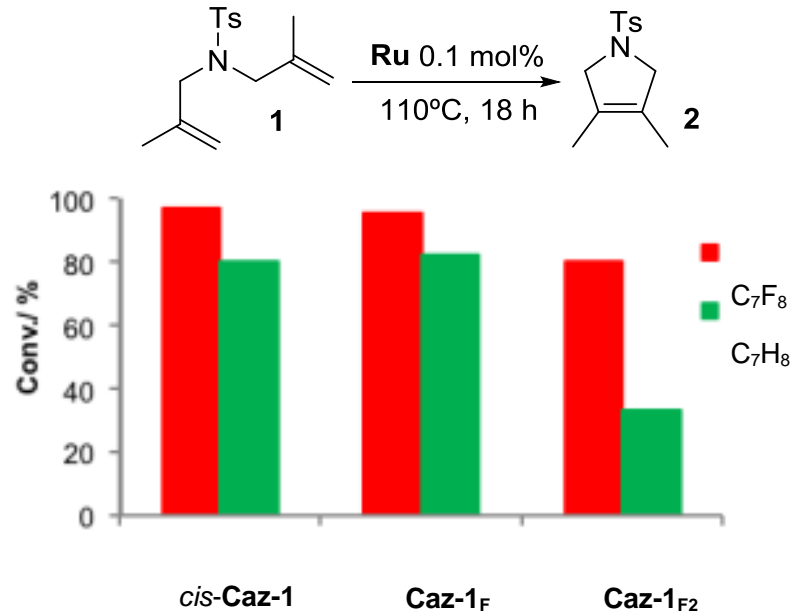

Figure 7. RCM properties of Ru-F pre-catalysts and cisCaz-1 in toluene and perfluorotoluene under inert atmosphere.

Scope of the reaction. The catalytic efficiency of the mono-fluoride complex was next investigated, in a conventional solvent (toluene), at $110^{\circ} \mathrm{C}$ (Figure 8 ). Caz-1 $_{\mathrm{F}}$ proved highly active at $0.1 \mathrm{~mol} \%$ for hindered and unhindered malonate and tosylate derivatives. With 0.5 mol\% loading, Caz-1 $\mathbf{1}_{\mathrm{F}}$ enables enyne metathesis of $\mathbf{6}$, as well as the efficient and selective cross-metathesis of 8 with 9.
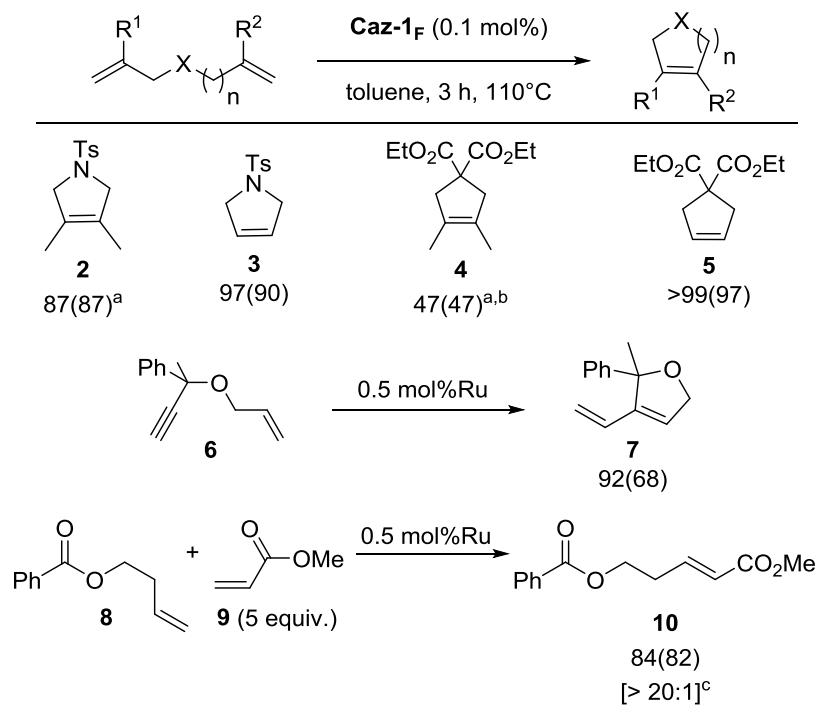

Reaction conditions: Caz-1 $\mathbf{F}(0.1 \mathrm{~mol} \%)$, substrate $(0.25 \mathrm{mmol})$, toluene $(0.5 \mathrm{~mL}), 3 \mathrm{~h}, 110^{\circ} \mathrm{C}$, under $\mathrm{Ar}$; average of 2 runs; conversions were determined by $\mathrm{GC}$; isolated yield in parentheses; ${ }^{\mathrm{a}}$ reaction in neat substrate; ${ }^{\mathrm{b}} 0.5 \mathrm{~mol} \% \mathrm{Ru}$, isolated as mixture, NMR yield; ${ }^{c} E / Z$ ratio determined by ${ }^{1} \mathrm{H}$ NMR.

Figure 8. Scope of the reaction employing $\mathrm{Caz}_{-1} \mathbf{1}_{\mathrm{F}}$.

\section{Conclusion}

The synthesis of the first Ru-F pre-catalysts for olefin metathesis reactions has been presented. Cis-Caz-1 reacts with $\mathrm{AgF}$ under mild conditions - rather than HF or equivalent reactants - affording isolable Ru-F species. Both $\mathbf{C a z}-\mathbf{1}_{\mathrm{F}}$ and $\mathbf{C a z}-\mathbf{1}_{\mathrm{F} 2}$ display the same cis geometry as their chloride precursor. In analogy to what has been observed by Caulton and co-workers with carbonyl complexes, a push-pull interaction involving the fluoride ligand ( $\pi$-donor) and L-type ligands ( $\pi$-acceptor) is invoked to stabilize the complexes (F-Ru(II)-P(OR $)_{3}$ bonding). Fluoride exchange reactions involving $\mathbf{C a z}_{\mathbf{F}} \mathbf{1}_{\mathrm{F}}$ with cisCaz-1 and trans-Caz-1 were performed. The selectivity toward only one product $\left(\mathbf{C a z}-\mathbf{1}_{\mathrm{F}}\right)$ rather than an equilibrium mixture supports the push-pull effect in the F-Ru(II)$\mathrm{P}(\mathrm{OR})_{3}$ bonding as a driving force for the process. Computational studies confirmed the stability of these complexes when compared to cis-Caz-1, with $\mathbf{C a z}_{\mathbf{F}} \mathbf{1}_{\mathbf{F}}$ being the most stable. The stability of the cis pre-catalysts influences their catalytic activity. A larger energy barrier was observed for $\mathbf{C a z}-\mathbf{1}_{\mathrm{F}}$ experimentally and in the computational study compared to cis-Caz-1. Nevertheless, both pre-catalysts display similar reactivity in olefin metathesis. Caz-1 $\mathbf{F}_{\mathbf{F}}$ is less active than the former precatalysts due to its higher stability in the cis form and the very small amount of active species generated. The effect of fluorinated solvents in catalysis was investigated. An overall enhancement of the catalytic activity was observed even for $\mathbf{C a z}_{\mathbf{- 1}} \mathbf{F}_{2}$, supporting the hypothesis of a stabilization of the NHC-Ru species by the fluorinated 
solvent rather than the fluorination of active species during the reaction. The catalytic results reported here are not as superior as predicted by literature reports having computationally addressed trans-Ru- $F$ species. In the present work, the cis-geometry of the species has an influence on the activity of the complexes, resulting in different catalytic properties compared to the hypothetical trans-Ru-F species. Although the search for a viable synthetic route leading to this species still remains elusive, the present experimental / computational study clearly highlights that this goal is indeed a worthy one. Efforts in this direction and in directions leading to longer living and more active metathesis catalysts are ongoing in our laboratory.

\section{EXPERIMENTAL SECTION}

$\left[\mathbf{R u}(\mathrm{Cl}) \mathbf{F}(\mathbf{I n d})\left(\mathrm{SIMes}_{\mathbf{2}}\left\{\mathbf{P}\left(\mathrm{O}^{\prime} \mathbf{P r}\right)_{3}\right\}\right], \mathrm{Caz}-\mathbf{1}_{\mathrm{F}}\right.$. Under an inert atmosphere of argon, $\mathrm{AgF}(52.2 \mathrm{mg}, 0.41 \mathrm{mmol})$ was added to a solution of cis-Caz-1 (303 mg, $0.34 \mathrm{mmol}$ ) in dichloromethane $(10 \mathrm{~mL}){ }^{24}$ The reaction mixture was stirred for $24 \mathrm{~h}$ at room temperature in the absence of light. The solution was filtered, the solvent was removed in vacuo leading to the product as a pale-brown solid in a quantitative yield (295 mg, 99\%). ${ }^{1} \mathrm{H}$ NMR $\left(\mathrm{CD}_{2} \mathrm{Cl}_{2}, 400\right.$ $\mathrm{MHz}): \delta(\mathrm{ppm})=0.57\left(\mathrm{~d},{ }^{3} \mathrm{~J}_{\mathrm{HH}}=5.9 \mathrm{~Hz}, 3 \mathrm{H}, \mathrm{CH}-\mathrm{CH}_{3}\right)$, $0.75\left(\mathrm{~d},{ }^{3} \mathrm{~J}_{\mathrm{HH}}=6.0 \mathrm{~Hz}, 3 \mathrm{H}, \mathrm{CH}-\mathrm{CH}_{3}\right), 0.90\left(\mathrm{~d},{ }^{3} \mathrm{~J}_{\mathrm{HH}}=5.8\right.$ $\left.\mathrm{Hz}, 3 \mathrm{H}, \mathrm{CH}-\mathrm{CH}_{3}\right), 1.10\left(\mathrm{~d},{ }^{3} \mathrm{~J}_{\mathrm{HH}}=6.0 \mathrm{~Hz}, 3 \mathrm{H}, \mathrm{CH}-\mathrm{CH}_{3}\right)$, $1.38\left(\mathrm{~d},{ }^{3} \mathrm{~J}_{\mathrm{HH}}=6.1 \mathrm{~Hz}, 3 \mathrm{H}, \mathrm{CH}-\mathrm{CH}_{3}\right), 1.44\left(\mathrm{~d},{ }^{3} \mathrm{~J}_{\mathrm{HH}}=6.2\right.$ $\left.\mathrm{Hz}, 3 \mathrm{H}, \mathrm{CH}-\mathrm{CH}_{3}\right), 1.60$ (s, 3H, mesityl $\left.\mathrm{CH}_{3}\right), 1.83(\mathrm{~s}, 3 \mathrm{H}$, mesityl $\left.\mathrm{CH}_{3}\right), 2.33\left(\mathrm{~s}, 3 \mathrm{H}\right.$, mesityl $\left.\mathrm{CH}_{3}\right), 2.51(\mathrm{~s}, 3 \mathrm{H}$, mesityl $\left.\mathrm{CH}_{3}\right), 2.62$ (s, 3H, mesityl $\left.\mathrm{CH}_{3}\right), 2.69$ (s, 3H, mesityl $\left.\mathrm{CH}_{3}\right)$, $3.26\left(\mathrm{~m}, 1 \mathrm{H}, \mathrm{CH}-\mathrm{CH}_{3}\right), 3.47-3.58(\mathrm{~m}, 1 \mathrm{H}$, carbene $\left.\mathrm{H}^{4^{\prime}}\right)$, 3.80-4.03 $\left(\mathrm{m}, 3 \mathrm{H}\right.$, carbene $\left.\mathrm{H}^{4} \mathrm{H}^{5}\right), 4.26(\mathrm{~m}, 1 \mathrm{H}, \mathrm{CH}-$ $\left.\mathrm{CH}_{3}\right), 4.76\left(\mathrm{~m}, 1 \mathrm{H}, \mathrm{CH}-\mathrm{CH}_{3}\right), 6.03(\mathrm{~s}, 1 \mathrm{H}$, mesityl $\mathrm{CH})$, $6.32\left(\mathrm{~s}, 1 \mathrm{H}\right.$, indenylidene $\left.\mathrm{H}^{2}\right), 6.51(\mathrm{~s}, 1 \mathrm{H}$, mesityl $\mathrm{CH})$, 7.02 (s, 1H, mesityl CH), 7.04 (s, 1H, mesityl CH), 7.15 $\left(\mathrm{d},{ }^{3} \mathrm{~J}_{\mathrm{HH}}=7.2 \mathrm{~Hz}, 1 \mathrm{H}\right.$, indenylidene $\left.\mathrm{H}^{4}\right), 7.29-7.37(\mathrm{~m}$, $2 \mathrm{H}$, indenylidene $\mathrm{H}^{5}$ and $\left.\mathrm{H}^{6}\right), 7.37-7.42(\mathrm{~m}, 2 \mathrm{H}$, indenylidene $\left.\mathrm{H}^{10}\right), 7.43-7.49\left(\mathrm{~m}, 1 \mathrm{H}\right.$, indenylidene $\left.\mathrm{H}^{11}\right), 7.67(\mathrm{~d}$, ${ }^{3} \mathrm{~J}_{\mathrm{HH}}=7.2 \mathrm{~Hz}, 2 \mathrm{H}$, indenylidene $\left.\mathrm{H}^{9}\right), 8.93\left(\mathrm{~d},{ }^{3} \mathrm{~J}_{\mathrm{HH}}=7.1\right.$ $\mathrm{Hz}, 1 \mathrm{H}$, indenylidene $\left.\mathrm{H}^{7}\right) .{ }^{13} \mathrm{C}-\left\{{ }^{1} \mathrm{H}\right\} \mathrm{NMR}\left(\mathrm{CDCl}_{3} 100.6\right.$ $\mathrm{MHz}) \delta(\mathrm{ppm})=17.9\left(\mathrm{~s}\right.$, mesityl $\left.\mathrm{CH}_{3}\right), 18.9(\mathrm{~s}$, mesityl $\mathrm{CH}_{3}$ ), 19.1 (s, mesityl $\mathrm{CH}_{3}$ ), 20.5 (s, mesityl $\left.\mathrm{CH}_{3}\right), 20.7$ (s, mesityl $\mathrm{CH}_{3}$ ), 21.2 (s, mesityl $\mathrm{CH}_{3}$ ), $24.1\left(\mathrm{~s}, \mathrm{CH}-\mathrm{CH}_{3}\right.$ ), $24.2\left(\mathrm{~s}, \mathrm{CH}-\mathrm{CH}_{3}\right), 24.35\left(\mathrm{~s}, \mathrm{CH}-\mathrm{CH}_{3}\right), 24.4\left(\mathrm{~s}, \mathrm{CH}-\mathrm{CH}_{3}\right)$, $24.5\left(\mathrm{~s}, \mathrm{CH}-\mathrm{CH}_{3}\right), 24.6\left(\mathrm{~s}, \mathrm{CH}-\mathrm{CH}_{3}\right), 51.6$ (s, carbene $\left.\mathrm{C}^{4} \mathrm{H}\right), 51.8\left(\mathrm{~s}\right.$, carbene $\left.\mathrm{C}^{5} \mathrm{H}\right), 68.8\left(\mathrm{~d},{ }^{2} \mathrm{~J}_{\mathrm{CP}}=11.4 \mathrm{~Hz}\right.$, $\left.\mathrm{CH}-\mathrm{CH}_{3}\right), 69.9\left(\mathrm{~d},{ }^{2} \mathrm{~J}_{\mathrm{CP}}=9.3 \mathrm{~Hz}, \mathrm{CH}-\mathrm{CH}_{3}\right), 72.6$ (bs, $\mathrm{CH}-$ $\mathrm{CH}_{3}$ ), 117.3 (s, indenylidene $\mathrm{C}^{4} \mathrm{H}$ ), 127.5 (s, indenylidene $\left.\mathrm{C}^{9} \mathrm{H}\right), 128.6\left(\mathrm{~s}\right.$, indenylidene $\left.\mathrm{C}^{11} \mathrm{H}\right), 129.1(\mathrm{~s}$, indenylidene $\left.\mathrm{C}^{10} \mathrm{H}\right), 129.4\left(\mathrm{~s}\right.$, indenylidene $\left.\mathrm{C}^{6} \mathrm{H}\right), 129.6(\mathrm{~s}$, indenylidene $\mathrm{C}^{5} \mathrm{H}$ ), 129.7 (s, mesityl $\mathrm{CH}$ ), 130.1 (s, mesityl $\mathrm{CH}), 130.4\left(\mathrm{~s}\right.$, mesityl $\mathrm{CH}$ ), 130.5 (s, indenylidene $\mathrm{C}^{7} \mathrm{H}$ ), $134.5\left(\mathrm{~s}, \mathrm{C}^{\mathrm{IV}}\right), 135.3\left(\mathrm{~s}, \mathrm{C}^{\mathrm{IV}}\right), 136.3\left(\mathrm{~s}, \mathrm{C}^{\mathrm{IV}}\right), 136.8\left(\mathrm{~s}, \mathrm{C}^{\mathrm{IV}}\right)$, $137.0\left(\mathrm{~s}, \mathrm{C}^{\mathrm{IV}}\right), 138.1\left(\mathrm{bs}, 2 \mathrm{C}^{\mathrm{IV}}\right), 138.7\left(\mathrm{~s}, \mathrm{C}^{\mathrm{IV}}\right), 139.0(\mathrm{~s}$, $\left.\mathrm{C}^{\mathrm{IV}}\right), 139.8\left(\mathrm{~d},{ }^{3} \mathrm{~J}_{\mathrm{CP}}=14.6 \mathrm{~Hz}\right.$, indenylidene $\left.\mathrm{C}^{2}\right), 140.2(\mathrm{~s}$, $\left.\mathrm{C}^{\mathrm{IV}}\right), 141.6\left(\mathrm{~m}\right.$, indenylidene $\left.\mathrm{C}^{7 \mathrm{a}}\right), 142.9\left(\mathrm{~s}, \mathrm{C}^{\mathrm{IV}}\right), 209.1$ $\left(\mathrm{d},{ }^{2} J_{\mathrm{CP}}=16.0 \mathrm{~Hz}\right.$, carbene $\left.\mathrm{C}^{2}\right), 289.6\left(\mathrm{~d},{ }^{2} J_{\mathrm{CP}}=25.5 \mathrm{~Hz}\right.$, indenylidene $\left.\mathrm{C}^{1}\right) .{ }^{31} \mathrm{P}-\left\{{ }^{1} \mathrm{H}\right\}$ NMR $\left(\mathrm{CD}_{2} \mathrm{Cl}_{2}, 162 \mathrm{MHz}\right) \delta$ $(\mathrm{ppm})=131.4\left(\mathrm{~d},{ }^{2} \mathrm{JPF}_{\mathrm{PF}}=286 \mathrm{~Hz}, \mathrm{P}\left(\mathrm{O}^{\prime} \mathrm{Pr}\right)_{3}\right) \cdot{ }^{19} \mathrm{~F}-\left\{{ }^{1} \mathrm{H}\right\} \mathrm{NMR}$ $\left(\mathrm{CD}_{2} \mathrm{Cl}_{2}, 282.2 \mathrm{MHz}\right) \delta(\mathrm{ppm})=-217.2\left(\mathrm{~d},{ }^{2} J_{\mathrm{PF}}=286 \mathrm{~Hz}\right.$, F). Elem. anal.: Calcd. for $\mathrm{C}_{45} \mathrm{H}_{57} \mathrm{ClFN}_{2} \mathrm{O}_{3} \mathrm{PRu}$ : C, 62.81; $\mathrm{H}, 6.68$; N, 3.26. Found: C, 62.72; H, 6.59; N, 3.16.
[RuF ${ }_{2}$ (Ind)(SIMes)\{P(O'Pr) $\left.\left.{ }_{3}\right\}\right]$, Caz-1 $\mathbf{F}_{\mathrm{F} 2}$. Under inert atmosphere, AgF (104 mg, $0.82 \mathrm{mmol}$ ) was added to a solution of cis-Caz-1 (298 mg, $0.34 \mathrm{mmol}$ ) in dichloromethane $(10 \mathrm{~mL}) .{ }^{25}$ The reaction mixture was stirred for $24 \mathrm{~h}$ at room temperature in the absence of light. The solution was filtered, the solvent was removed in vacuo leading to the product as a pale-brown solid in a quantitative yield (280 mg, 98\%). ${ }^{1} \mathrm{H}$ NMR $\left(\mathrm{CD}_{2} \mathrm{Cl}_{2}, 400 \mathrm{MHz}\right)$ : $\delta(\mathrm{ppm})=0.5-1.5\left(\mathrm{~m}, 18 \mathrm{H}, \mathrm{CH}-\mathrm{CH}_{3}\right), 1.66(\mathrm{~s}, 3 \mathrm{H}$, mesityl $\left.\mathrm{CH}_{3}\right), 1.83\left(\mathrm{~s}, 3 \mathrm{H}\right.$, mesityl $\left.\mathrm{CH}_{3}\right), 2.37$ (s, 3H, mesityl $\mathrm{CH}_{3}$ ), 2.40 (s, 3H, mesityl $\left.\mathrm{CH}_{3}\right), 2.65$ (s, 3H, mesityl $\left.\mathrm{CH}_{3}\right), 2.68\left(\mathrm{~s}, 3 \mathrm{H}\right.$, mesityl $\left.\mathrm{CH}_{3}\right), 3.46-3.58(\mathrm{~m}, 1 \mathrm{H}$, carbene $\left.\mathrm{H}^{4}\right)$, 3.80-4.00 $\left(\mathrm{m}, 3 \mathrm{H}\right.$, carbene $\left.\mathrm{H}^{4} \mathrm{H}^{5}\right), 6.01(\mathrm{~s}, 1 \mathrm{H}$, mesityl $\mathrm{CH}), 6.38\left(\mathrm{~s}, 1 \mathrm{H}\right.$, indenylidene $\left.\mathrm{H}^{2}\right), 6.43(\mathrm{~s}$, mesityl $\mathrm{CH}), 7.08(\mathrm{~s}, 1 \mathrm{H}$, mesityl $\mathrm{CH}), 7.09(\mathrm{~s}, 1 \mathrm{H}$, mesityl $\mathrm{CH}), 7.16\left(\mathrm{~d},{ }^{3} \mathrm{~J}_{\mathrm{HH}}=7.1 \mathrm{~Hz}, 1 \mathrm{H}\right.$, indenylidene $\left.\mathrm{H}^{4}\right), 7.30$ $\left(\mathrm{dd},{ }^{3} \mathrm{~J}_{\mathrm{HH}}=7.1 \mathrm{~Hz},{ }^{3} \mathrm{~J}_{\mathrm{HH}}=7.4 \mathrm{~Hz}, 2 \mathrm{H}\right.$, indenylidene $\mathrm{H}^{5}$ ), $7.35 \mathrm{dd},{ }^{3} \mathrm{JHH}_{\mathrm{HH}}=7.1 \mathrm{~Hz},{ }^{3} \mathrm{~J}_{\mathrm{HH}}=7.4 \mathrm{~Hz}, 2 \mathrm{H}$, indenylidene $\mathrm{H}^{6}$ ), $7.40\left(\mathrm{dd},{ }^{3} \mathrm{~J}_{\mathrm{HH}}=7.5 \mathrm{~Hz},{ }^{3} \mathrm{~J}_{\mathrm{HH}}=7.5 \mathrm{~Hz}, 2 \mathrm{H}\right.$, indenylidene $\left.\mathrm{H}^{10}\right), 7.47\left(\mathrm{dd},{ }^{3} \mathrm{~J}_{\mathrm{HH}}=7.2 \mathrm{~Hz},{ }^{3} J_{\mathrm{HH}}=7.4 \mathrm{~Hz}, 1 \mathrm{H}\right.$ indenylidene $\left.\mathrm{H}^{11}\right), 7.67\left(\mathrm{~d},{ }^{3} \mathrm{~J}_{\mathrm{HH}}=7.5 \mathrm{~Hz}, 2 \mathrm{H}\right.$, indenylidene $\left.\mathrm{H}^{9}\right), 9.02\left(\mathrm{~d},{ }^{3} \mathrm{~J}_{\mathrm{HH}}=7.0 \mathrm{~Hz}, 1 \mathrm{H}\right.$, indenylidene $\left.\mathrm{H}^{7}\right)$. The isopropyl protons were observed clearly at lower temperature: ${ }^{1} \mathrm{H}$ NMR $\left(\mathrm{CD}_{2} \mathrm{Cl}_{2}, 400 \mathrm{MHz}, 223 \mathrm{~K}\right): \delta(\mathrm{ppm})=$ $3.16\left(\mathrm{~m}, 1 \mathrm{H}, \mathrm{CH}-\mathrm{CH}_{3}\right), 3.50\left(\mathrm{~m}, 1 \mathrm{H}, \mathrm{CH}-\mathrm{CH}_{3}\right), 4.64(\mathrm{~m}$, $\left.1 \mathrm{H}, \mathrm{CH}-\mathrm{CH}_{3}\right) .{ }^{13} \mathrm{C}-\left\{{ }^{1} \mathrm{H}\right\}$ NMR $\left(\mathrm{CDCl}_{3} 100.6 \mathrm{MHz},\right) \delta$ $(\mathrm{ppm})=17.5\left(\mathrm{~s}\right.$, mesityl $\left.\mathrm{CH}_{3}\right), 18.1\left(\mathrm{~s}\right.$, mesityl $\left.\mathrm{CH}_{3}\right), 18.6$ (s, mesityl $\mathrm{CH}_{3}$ ), 20.4 (s, mesityl $\mathrm{CH}_{3}$ ), 20.8 (s, mesityl $\mathrm{CH}_{3}$ ), 21.2 (s, mesityl $\mathrm{CH}_{3}$ ), 23.6-24.7 (bs, $6 \mathrm{CH}-\mathrm{CH}_{3}$ ), $51.4\left(\mathrm{~s}\right.$, carbene $\left.\mathrm{C}^{4} \mathrm{H}\right), 51.8\left(\mathrm{~s}\right.$, carbene $\left.\mathrm{C}^{5} \mathrm{H}\right), 117.0(\mathrm{~s}$, indenylidene $\mathrm{C}^{4} \mathrm{H}$ ), 127.3 (s, indenylidene $\mathrm{C}^{9} \mathrm{H}$ ), 128.3 (s, indenylidene $\mathrm{C}^{11} \mathrm{H}$ ), 129.0 (s, indenylidene $\mathrm{C}^{10} \mathrm{H}$ ), 129.1 (s, indenylidene $\left.\mathrm{C}^{6} \mathrm{H}\right), 129.3$ (s, indenylidene $\left.\mathrm{C}^{5} \mathrm{H}\right), 129.5$ (s, mesityl CH), 130.1 (s, mesityl CH), 130.2 (s, mesityl $\mathrm{CH}), 130.3\left(\mathrm{~s}\right.$, indenylidene $\left.\mathrm{C}^{7} \mathrm{H}\right), 135.1\left(\mathrm{~s}, \mathrm{C}^{\mathrm{IV}}\right), 135.7$ $\left(\mathrm{s}, \mathrm{C}^{\mathrm{IV}}\right), 136.5\left(\mathrm{~s}, \mathrm{C}^{\mathrm{IV}}\right), 136.7\left(\mathrm{~s}, \mathrm{C}^{\mathrm{IV}}\right), 137.1\left(\mathrm{~s}, \mathrm{C}^{\mathrm{IV}}\right), 137.9$ (bs, $\left.2 \mathrm{C}^{\mathrm{IV}}\right), 139.0\left(\mathrm{~s}, \mathrm{C}^{\mathrm{IV}}\right), 139.1\left(\mathrm{~s}, \mathrm{C}^{\mathrm{IV}}\right), 140.2\left(\mathrm{~d},{ }^{3} \mathrm{~J}_{\mathrm{CP}}=\right.$ $14.3 \mathrm{~Hz}$, indenylidene $\left.\mathrm{C}^{2}\right), 140.4\left(\mathrm{~s}, \mathrm{C}^{\mathrm{iv}}\right), 141.3(\mathrm{~m}$, indenylidene $\left.\mathrm{C}^{7 \mathrm{a}}\right), 142.1\left(\mathrm{~s}, \mathrm{C}^{\mathrm{IV}}\right)$. Characteristic peaks were observed at lower temperature (more complicated spectrum due to limited rotation of the ligands): ${ }^{13} \mathrm{C}-\left\{{ }^{1} \mathrm{H}\right\}$ $\operatorname{NMR}\left(\mathrm{CDCl}_{3} 100.6 \mathrm{MHz}, 223 \mathrm{~K}\right) \delta(\mathrm{ppm})=68.4\left(\mathrm{~d},{ }^{2} \mathrm{JPP}_{\mathrm{CP}}=\right.$ $\left.10.2 \mathrm{~Hz}, \mathrm{CH}-\mathrm{CH}_{3}\right), 69.4\left(\mathrm{~d},{ }^{2} \mathrm{~J}_{\mathrm{CP}}=7.4 \mathrm{~Hz}, \mathrm{CH}-\mathrm{CH}_{3}\right), 72.0$ (bs, ${ }^{2} J_{\mathrm{CP}}=3.6 \mathrm{~Hz}, \mathrm{CH}-\mathrm{CH}_{3}$ ), 211.1 (m, carbene $\mathrm{C}^{2}$ ), $287.0\left(\mathrm{~m}\right.$, indenylidene $\left.\mathrm{C}^{1}\right) .{ }^{31} \mathrm{P}-\left\{{ }^{1} \mathrm{H}\right\}$ NMR $\left(\mathrm{CD}_{2} \mathrm{Cl}_{2}, 162\right.$ $\mathrm{MHz}) \delta(\mathrm{ppm})=131.5\left(\mathrm{~d},{ }^{2} J_{\mathrm{PF}}=286 \mathrm{~Hz}, \mathrm{P}\left(\mathrm{O}^{\prime} \mathrm{Pr}\right)_{3}\right) .{ }^{19} \mathrm{~F}-$ $\left\{{ }^{1} \mathrm{H}\right\} \operatorname{NMR}\left(\mathrm{CD}_{2} \mathrm{Cl}_{2}, 376.3 \mathrm{MHz}\right) \delta(\mathrm{ppm})=-237.2$ (br.s, $\left.\mathrm{F}_{\text {trans } \mathrm{NHC}}\right),-217.7\left(\mathrm{~d},{ }^{2} \mathrm{~J}_{\mathrm{PF}}=286 \mathrm{~Hz}, \mathrm{~F}_{\text {transPhosphite }}\right.$ ). Elem. anal.: Calcd. for $\mathrm{C}_{45} \mathrm{H}_{57} \mathrm{~F}_{2} \mathrm{~N}_{2} \mathrm{O}_{3} \mathrm{PRu}$ : C, 64.04; $\mathrm{H}, 6.81 ; \mathrm{N}$, 3.32. Found: $\mathrm{C}, 64.03 ; \mathrm{H}, 6.89 ; \mathrm{N}, 3.39$.

\section{ASSOCIATED CONTENT}

Procedures for catalysis, NMR spectra of complexes and catalysis products, procedures and NMR spectra for fluoride exchange reactions and isomerization study, crystallographic data and structure refinement for complexes Caz-1 $\mathbf{F}$ and Caz-1 $1_{\mathbf{F} 2}$, computational details. This material is available free of charge via the Internet at http://pubs.acs.org. Crystallographic data for complexes Caz-1 $\mathbf{F}_{\mathrm{F}}$ and $\mathbf{C a z}-\mathbf{1}_{\mathrm{F} 2}$ in $\mathrm{CIF}$ format can also be obtained free of charge from the Cambridge Crystallographic Data Centre via www.ccdc.cam.ac.uk/data request/cif (CCDC/911524911525) 


\section{AUTHOR INFORMATION}

\section{Corresponding Author}

*EaStCHEM School of Chemistry University of St Andrews, KY16 9ST, St Andrews, UK.

Fax: (+)44 1334463808.

E-mail: cc111@st-andrews.ac.uk.

\section{ACKNOWLEDGMENT}

The authors gratefully acknowledge the EC through the 7th framework program (grant CP-FP 211468-2 EUMET), the Royal Society (University Research Fellowship to CSJC) for financial support and Umicore for the gift of cis-Caz-1.

\section{REFERENCES}

(1) O'Hagan, D. Chem. Soc. Rev. 2008, 37, 308-319.

(2) Torrens, H. Coord. Chem. Rev. 2005, 249, 1957-1985.

(3) (a) Pagenkopf, B. L.; Carreira, E. M. Tetrahedron. Lett. 1998, 39, 9593-9596. (b) Gauthier, D. R.; Carreira, E. M. Angew. Chem. Int. Ed. 1996, 35, 2363-2365. (c) Pagenkopf, B. L.; Carreira E. M. Chem. Eur. J. 1999, 5, 3437-3442. (d) Verdaguer, X.; Lange, U. E. W.; Reding, M. T.; Buchwald, S. L. J. Am. Chem. Soc. 1996, 118, 6784-6785. (e) Dorta, R.; Egli, P.; Zurcher, F.; Togni, A. J. Am. Chem. Soc. 1997, 119, 1085710858. (f) Kruger, J.; Carreira, E. M. J. Am. Chem. Soc. 1998, 120, 837-838. (g) Mezzetti, A.; Becker, C. Helv. Chim. Act. 2002, 85, 2686-2703. (h) Barthazy, P.; Stoop, R. M.; Wörle, M.; Togni, A.; Mezzetti, A. Organometallics 2000, 2844-2852.

(4) (a) Pearson, R. G. J. Am. Chem. Soc. 1963, 85, 35333539. (b) Caulton, K. G. New. J. Chem. 1994, 18, 25-41. (c) Poulton, J. T.; Sigalas, M. P.; Folting, K.; Streib, W. E.; Eisenstein, O.; Caulton, K. G. Inorg. Chem. 1994, 33, 1476-1485. (d) Doherty, N. M.; Hoffman, N. W. Chem. Rev. 1991, 91, 553573. (e) Kiplinger, J. L.; Richmond, T. G.; Osterberg, C. E. Chem. Rev. 1994, 94, 373-431. (f) Murphy, E. F.; Murugavel, R.; Roesky, H. W. Chem. Rev. 1997, 97, 3425-3468. (g) Coalter, J. N.; Huffman, J. C.; Streib, W. E.; Caulton, K. G. Inorg. Chem. 2000, 39, 3757-3764. (h) Burch, R. R.; Harlow, R. L.; Ittel, S. D. Organometallics 1987, 6, 982-987.

(5) (a) Braun, T.; Steffen, A.; Schorlemer, V.; Neumann, B.; Stammler, H. G. Dalton Trans. 2005, 3331-3336. (b) Yahav, A.; Goldberg, I.; Vigalok, A. Inorg. Chem. 2005, 44, 1547-1553. (c) Cooper, A. C.; Folting, K.; Huffman, J. C.; Caulton, K. G. Organometallics 1997, 16, 505-507. (d) Brewer, S. A.; Holloway, J. H.; Hope, E. G. J. Chem. Soc., Dalton Trans. 1994, 10671071. (e) Brewer, S. A.; Coleman, K. S.; Fawcett, J.; Holloway, J. H.; Hope, E. G.; Russell, D. R.; Watson, P. G. J. Chem. Soc., Dalton Trans. 1995, 1073-1077. (f) Coleman, K. S.; Fawcett, J.; Holloway, J. H.; Hope, E. G.; Russell, D. R. J. Chem. Soc., Dalton Trans. 1997, 3557-3562. (g) Coleman, K. S.; Fawcett, J.; Harding, D. A. J.; Hope, E. G.; Singh, K.; Solan, G. A. Eur. J. Inorg. Chem. 2010, 4130-4138. (h) Fawcett, J.; Harding, D. A. J.; Hope, E. G.; Singh, K.; Solan, G. A. Dalton Trans. 2009, 6861-6870. (i) Coleman, K. S.; Holloway, J. H.; Hope, E. G. J. Chem. Soc., Dalton Trans. 1997, 1713-1718. (j) Marshall, C. J.; Peacock, R. D.; Russell, D. R.; Wilson, I. L. J. Chem. Soc. D 1970, 1643-1644. (k) Hewitt, A. J.; Holloway, J. H.; Peacock, R. D.; Raynor, J. B.; Wilson, I. L. J. Chem. Soc., Dalton Trans. 1976, 579-583.

(6) Fraser, S. L.; Antipin, M. Y.; Khroustalyov, V. N.; Grushin, V. V. J. Am. Chem. Soc. 1997, 119, 4769-4770.

(7) Amii, H.; Uneyama, K. Chem. Rev. 2009, 109, 21192183.

(8) (a) Reade, S. P.; Nama, D.; Mahon, M. F.; Pregosin, P. S.; Whittlesey, M. K. Organometallics 2007, 26, 3484-3491. (b) Reade, S. P.; Mahon, M. F.; Whittlesey, M. K. J. Am. Chem. Soc. 2009, 131, 1847-1861.

(9) Sanford, M. S.; Love, J. A.; Grubbs, R. H. J. Am. Chem. Soc. 2001, 123, 6543-6554.
(10) Naumov, S.; Buchmeiser, M. R. J. Phys. Org. Chem. 2008, 21, 963-970.

(11) (a) Seiders, T. J.; Ward, D. W.; Grubbs, R. H. Org. Lett. 2001, 3, 3225-3228. (b) Krause, J. O.; Nuyken, O.; Wurst, K.; Buchmeiser, M. R. Chem. Eur. J. 2004, 10, 777-784. (c) Halbach, T. S.; Mix, S.; Fischer, D.; Maechling, S.; Krause, J. O.; Sievers, C.; Blechert, S.; Nuyken, O.; Buchmeiser, M. R. J. Org. Chem. 2005, 70, 4687-4694. (d) Tanaka, K.; Böhm, V. P. W.; Chadwick, D.; Roeper, M.; Braddock, D. C. Organometallics 2006, 25, 5696-5698.

(12) (a) Gawin, R.; Grela, K. Eur. J. Inorg. Chem. 2012, 1477-1484. (b) Caskey, S. R.; Stewart, M. H.; Ahn, Y. J.; Johnson, M. J. A.; Rowsell, J. L. C.; Kampf, J. W. Organometallics 2007, 26, 1912-1923.

(13) (a) Bantreil, X.; Schmid, T. E.; Randall, R. A. M.; Slawin, A. M. Z.; Cazin, C. S. J. Chem. Commun. 2010, 46, 71157117. (b) Schmid, T. E.; Bantreil, X.; Citadelle, C. A.; Slawin, A. M. Z.; Cazin, C. S. J. Chem. Commun. 2011, 47, 7060-7062. (c) Songis, O.; Slawin, A. M. Z.; Cazin, C. S. J. Chem. Commun. 2012, 48, 1266-1268. (d) Bantreil, X.; Poater, A.; UrbinaBlanco, C. A.; Bidal, Y. D.; Falivene, L.; Randall, R. A. M.; Cavallo, L.; Slawin, A. M. Z.; Cazin, C. S. J. Organometallics 2012, 31, 7415-7426. (e) Urbina-Blanco, C. A.; Bantreil, X.; Wappel, J.; Schmid, T. E.; Slawin, A. M. Z.; Slugovc, C.; Cazin, C. S. J. Organometallics 2013, 32, 6240-6247. (f) Leitgeb, A.; Wappel, J.; Urbina-Blanco, C. A.; Strasser, S.; Wappl, C.; Cazin, C. S. J.; Slugovc, C. Monatsh. Chem. 2014, 145, 15131517.

(14) See Supporting Information section 3 page S10.

(15) CCDC-911524 contains the supporting crystallographic data for $\mathbf{C a z}-\mathbf{1}_{\mathrm{F}}$. These data can be obtained free of charge from the Cambridge Crystallographic Data Centre via www.ccdc.cam.ac.uk/data_request/cif.

(16) CCDC-911525 contains the supporting crystallographic data for $\mathbf{C a z}-\mathbf{1}_{\mathrm{F2}}$. These data can be obtained free of charge from the Cambridge Crystallographic Data Centre via www.ccdc.cam.ac.uk/data_request/cif.

(17) See Supporting Information section 5 page S12.

(18) See Supporting Information section 5.2 page S13.

(19) See computational details in the Supporting Information.

(20) Falivene, L.; Poater, A.; Cazin, C. S. J.; Slugovc, C.; Cavallo, L. Dalton Trans. 2013, 42, 7312-7317.

(21) Slugovc, C.; Perner, B.; Stelzer, F.; Mereiter, K. Organometallics 2004, 23, 3622-3626.

(22) See Supporting Information section 6.3 page $S 16$.

(23) Samojłowicz, C.; Bieniek, M.; Pazio, A.; Makal, A.; Wozniak, K.; Poater, A.; Cavallo, L.; Wojcik, J.; Zdanowski, K.; Grela, K. Chem. Eur. J. 2011, 17, 12981-12993.

(24) The granulometry of AgF has an impact on the efficiency of the chloride exchange reaction in such heterogeneous conditions, see ref 6 . 
The reaction of cis-Caz-1 with silver fluoride affords the first Ru-F pre-catalysts for olefin metathesis reactions. Catalytic studies with Ru-F species were performed and highlight the high catalytic efficacy of the monofluorinate pre-catalyst $\left(\mathbf{C a z}-\mathbf{1}_{\mathrm{F}}\right)$. DFT calculations help to rationalize the observed reactivity and stability of the novel complexes.

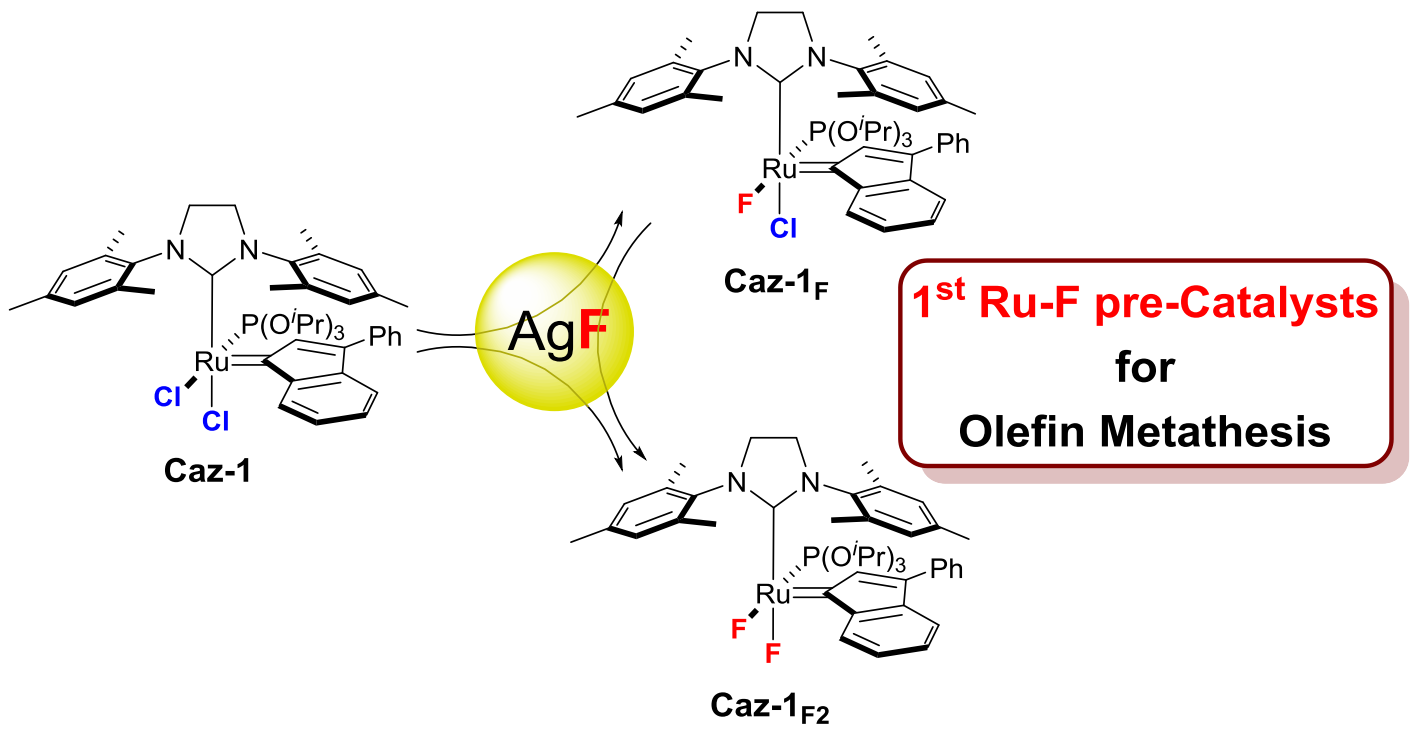

9 